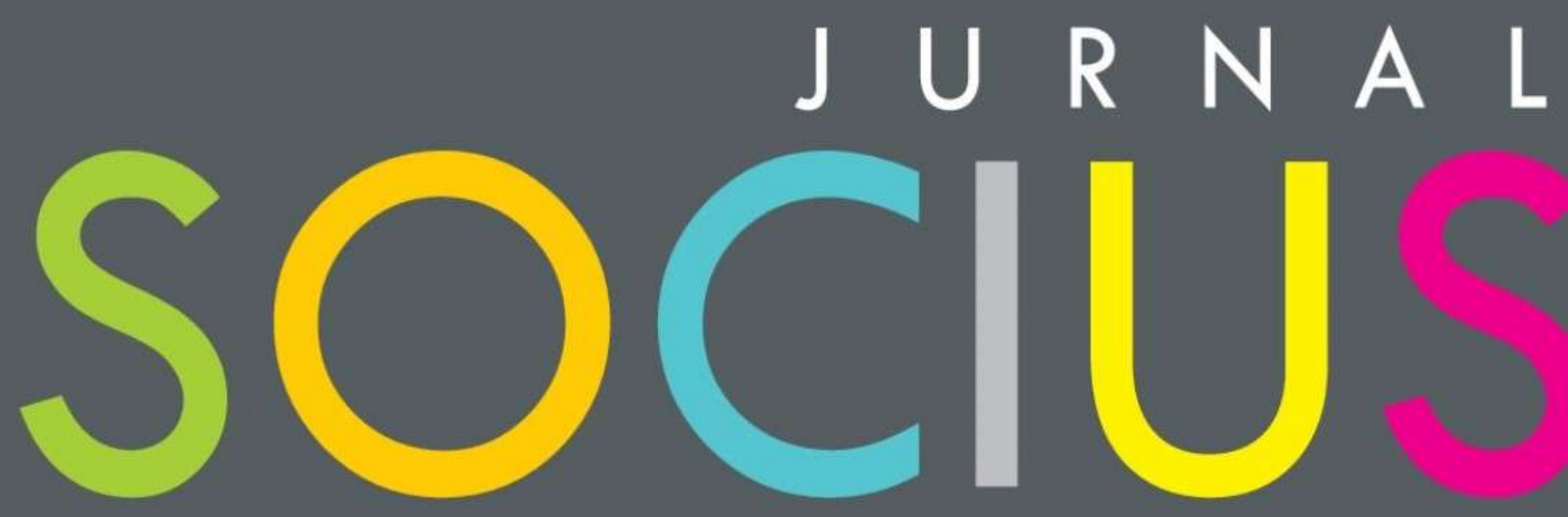

Journal of Sociology Research and Education

DITERBITKAN OLEH :

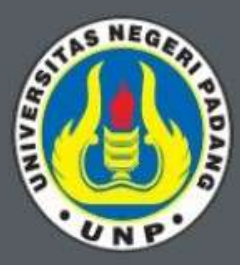

LABOR JURUSAN SOSIOLOGI FAKULTAS ILMU SOSIAL UNIVERSITAS NEGERI PADANG

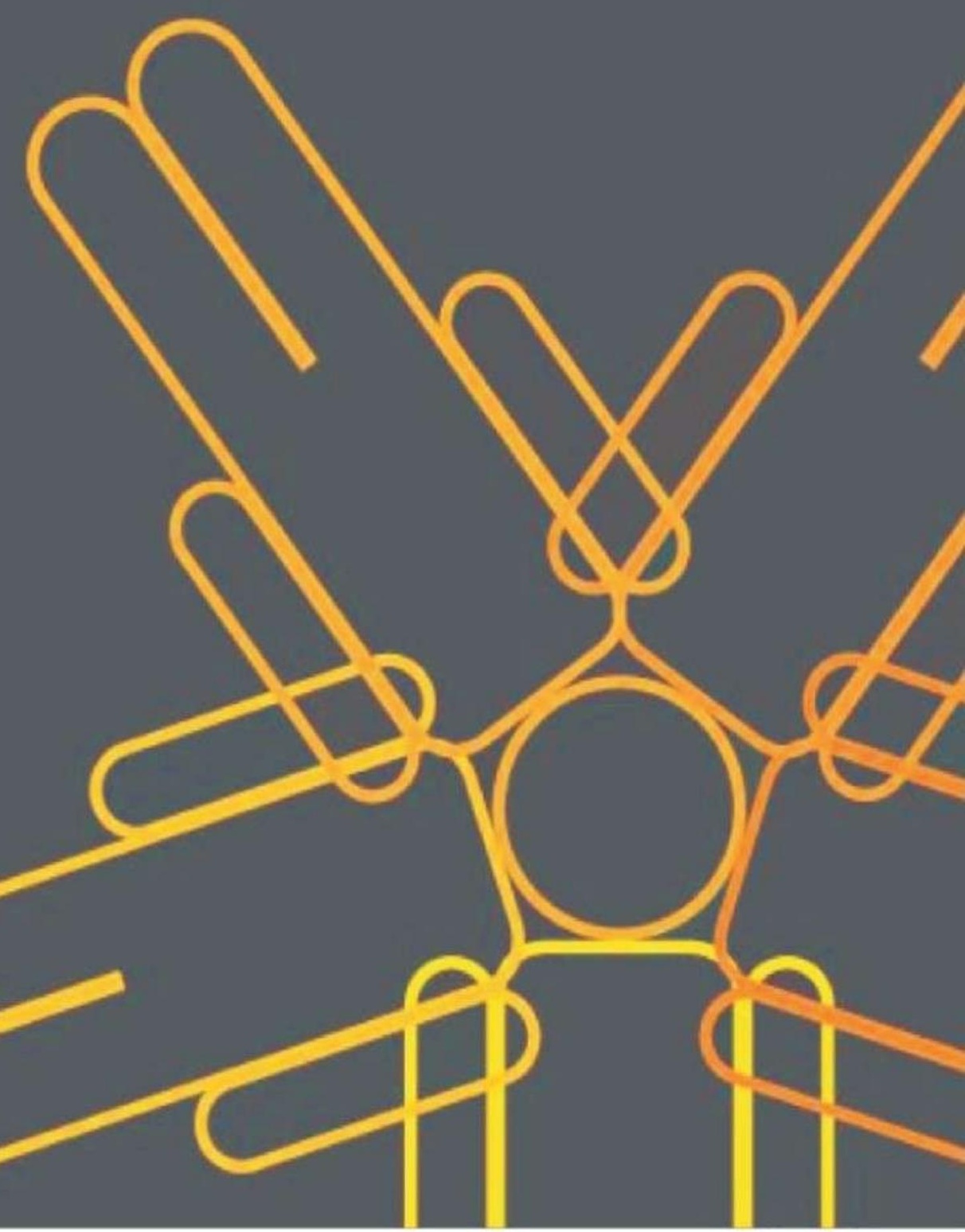




\section{SOCIUS}

Vol. 4, No.2, Th. 2017

ISSN : 2356-4180 (cetak)

2442-8663 (online)

\begin{tabular}{|c|c|}
\hline $\begin{array}{c}\text { REDAKSI } \\
\text { JURNAL SOCIUS }\end{array}$ & DAFTAR ISI \\
\hline $\begin{array}{l}\text { Ketua Dewan Penyunting : } \\
\text { Dr. Erianjoni, S.Sos., M.Si. } \\
\text { Wakil Ketua Dewan Penyunting : } \\
\text { Selinaswati, S.Sos., M.A., Ph.D. }\end{array}$ & $\begin{array}{c}\text { Abdul Salam } \\
\text { Bulan Bintang dibawah Kuasa Beringin: Parmusi } \\
\text { Padang Pariaman Masa Orde Baru } \\
\text { Halaman 61-73 }\end{array}$ \\
\hline $\begin{array}{c}\text { Dewan Penasehat: } \\
\text { Prof. Dr. Syafri Anwar, M.Pd. } \\
\text { (Universitas Negeri Padang) } \\
\text { Prof. Dr. Mestika Zed, MA. } \\
\text { (Universitas Negeri Padang) } \\
\text { Prof. Dasman Lanin, M.Pd., Ph. D. } \\
\text { (Universitas Negeri Padang) } \\
\text { Bakhrul Khair Amal, SE.,M.Si. } \\
\text { (Universitas Negeri Medan) } \\
\text { Prof. Dr. Ferdinand Kerebungu, M.Si. } \\
\text { (Universitas Negeri Manado) } \\
\text { Dr.rer.nat. Nurhadi, S.Ant., M. Hum. } \\
\text { (Universitas Negeri Solo) } \\
\text { Drs. Emizal Amri, M.Pd., M.Si. } \\
\text { (Universitas Negeri Padang) } \\
\text { Adri Febrianto, S.Sos., M.Si. } \\
\text { (Universitas Negeri Padang) } \\
\text { Drs. Ikhwan, M.Si. } \\
\text { (Universitas Negeri Padang) }\end{array}$ & $\begin{array}{c}\text { Delmira Syafrini dan Reno Fernandes } \\
\text { Dampak Revitalisasi Kota Sawahlunto Dari } \\
\text { Kota Tambang Menjadi Kota Wisata Tambang Berbudaya Pada } \\
\text { Kehidupan Sosial Ekonomi Masyarakat } \\
\text { Kota Sawahlunto } \\
\text { Halaman } 74-82 \\
\\
\text { Erda Fitriani, Selinaswati dan Desy Mardhiah } \\
\text { Partisipasi Masyarakat Dalam Pembangunan } \\
\text { Ekowisata Sungai Pinang } \\
\text { Studi Kasus: Nagari Sungai Pinang Kecamatan Koto IX Tarusan } \\
\text { Kabupaten Pesisir Selatan Sumatera Barat } \\
\text { Halaman } 83-96 \\
\text { Erianjoni } \\
\text { Pengembangan Materi Ajar Sosiologi Tentang Mitigasi Bencana } \\
\text { Berbasis Kearifan Lokal Di Kota Padang } \\
\text { Halaman 97-108 }\end{array}$ \\
\hline $\begin{array}{l}\text { Dewan Penyunting: } \\
\text { Dr. Eka Vidya Putra,S.Sos,.M.Si. } \\
\text { Dr. Desy Mardiah,S.Sos..S.Thi,.M.Si } \\
\text { Ike Sylvia,S.IP,.M.Si. } \\
\text { M. Isa Gautama,S.Pd,.M.Si. } \\
\text { Reno Fernandes, S.Pd., M.Pd. }\end{array}$ & $\begin{array}{c}\text { Muhammad Hidayat } \\
\text { Studi Pengaruh Kemandirian Mahasiswa Yogyakarta Terhadap Perstasi } \\
\text { Akademik: Respon } 60 \text { Mahasiswa Di Yogyakarta } \\
\text { Halaman 109-119 }\end{array}$ \\
\hline $\begin{array}{c}\text { Layout Editor : } \\
\text { Rhavy Ferdyan, S.Pd. }\end{array}$ & $\begin{array}{c}\text { Reno Fernandes } \\
\text { Adaptasi Sekolah Terhadap Kebijakan Pendidikan Inklusif } \\
\text { Halaman 120-126 }\end{array}$ \\
\hline $\begin{array}{l}\text { Technical Support: } \\
\text { Rudi Mahesa, A.Md. }\end{array}$ & $\begin{array}{c}\text { Selinaswati dan Erda Fitriani } \\
\text { Peran Sekolah Dalam Antisipasi Keracunan } \\
\text { Pangan Jajanan Anak Sekolah-PJAS }\end{array}$ \\
\hline $\begin{array}{l}\text { Alamat Redaksi: } \\
\text { Jurusan Sosiologi FIS UNP } \\
\text { Jl. Prof.Dr.Hamka } \\
\text { Kampus UNP Air Tawar } \\
\text { e-mail: } \underline{\text { sosan@ @is.unp.ac.id }}\end{array}$ & $\begin{array}{c}\text { (Studi Kasus Tiga SD Di Air Tawar Timur Padang Sumatera Barat) } \\
\text { Halaman 127-134 }\end{array}$ \\
\hline $\begin{array}{l}\text { Penerbit } \\
\text { Labor Jurusan Sosiologi } \\
\text { Universitas Negeri Padang }\end{array}$ & \\
\hline
\end{tabular}




\title{
BULAN BINTANG DI BAWAH KUASA BERINGIN: PARMUSI PADANG PARIAMAN MASA ORDE BARU
}

\author{
Abdul Salam \\ Universitas Negeri Padang \\ Email: $\underline{\text { salampeacefull72@gmail.com }}$
}

\begin{abstract}
Abstrak
Sejak berakhirnya Demokrasi Terpimpin, eks pimpinan Masyumi awalnya berharap Presiden Soeharto bersedia untuk merehabilitasi, sekaligus mengizinkan partai "bulan bintang" itu tampil di pentas politik. Namun, harapan itu kandas dan rezim militer hanya mengizinkan Partai Muslimin Indonesia (Parmusi) -sebagai representasi perwakilan Islam modernis. Sejak saat itu, Parmusi berdiri di seluruh Indonesia, termasuk di Kabupaten Padang Pariaman. Tulisan ini bertujuan untuk melihat kiprah Parmusi dalam Pemilu 1971 yang banyak intrik dibawah pengaruh Golkar sebagai partai pemerintah masa itu. Metode historis yang diterapkan dalam penelitian ini terdiri atas pengumpulan sumber (heuristik). Setelah heuristik, dilakukan kritik terhadap sumber temuan; interpretasi; dan historiografi.Parmusi Cabang Padang Pariaman berdiri tahun 1968, yang awalnya digagas oleh tokohtokoh eks Masyumi. Beragam intrik dan intervensi sengaja dilancarkan pemerintah Orde Baru, melalui Pelaksana Khusus Daerah (Laksusda). Intervensi itu, mulai dari mencampuri urusan rumah tangga partai, hingga dalam pelaksanaan kampanye, yang sering menguntungkan Golkar. Pelemahan terstruktur yang dilakukan pada masa itu, hanya mempunyai satu tujuan, yakni mendorong Golkar sebagai gerbong utama, sedangkan Parmusi hanya menjadi partai "semu" dalam menyemarakkan pesta demokrasi pertama masa Orde Baru.
\end{abstract}

Kata Kunci:Partai, Politik, Parmusi, Golkar, Intervensi.

\section{Abstract}

This article discusses the evolution of Partai Muslimin Indonesia (Parmusi) in Pariaman, West Sumatera and its role in Indonesian General Election in 1971 under the influence of Golkar. The Parmusi is the only one modern Islamic party to represent some Islamic parties allowed by Soeharto regime to participate in Indonesian politics in the early New Order Era.Since the end of Guided Democracy, the former leader of Masyumi (one of Islamic Party in Old Order Era) initially expected to President of Indonesia, Soeharto, would rehabilitate as well as allow the party to participate in Indonesian politics, however, the expectation failed. Thus Masyumi joined with Parmusi and itgrows rapidly all over Indonesia, including in Padang Pariaman in 1968. Historical method was applied in this study which was started with sources collection (heuristic), data critics, interpretation and historiography. It was found the various efforts of New Order Regime to impede this Islamic party including taking over the internal issues of the party during campaign which aimed to give benefit for Golkar, weakening the party internally and structurally which aimed to support the Golkar as foremost party, and allowing Parmusi as the pseudo-party to participate in the first General Election in 1971. These all intrigues, obstacles and intervention were performed by the Regime of New Order, especially through Pelaksana Khusus Daerah (Laksusda).

Key words: Party, Politics, Parmusi, Golkar, Intervention.

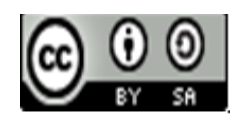




\section{Pendahuluan}

Partai Islam memainkan peranan penting dalam proses pendewasaan masa awal Orde Baru, ia mempunyai peranan yang lebih kompleks, meskipun sering terpinggirkan oleh kebijakan politik pemerintah. Partai Muslimin Indonesia (Parmusi) sebagai salah satu kekuatan politik pada awal Orde Baru, turut serta membangun sistem demokrasi di negeri ini, meskipun dalam perjalanan sejarahnya sering dikooptasi pemerintah.

Pada awal Orde Baru, eks pendukung Masyumi yang berjasa dalam menumbangkan Orde Lama, berharap dapat merehabilitasi Masyumi yang diberangus oleh Soekarno pada masa Demokrasi Terpimpin (Mintaredja, 1968: 1). Namun usulan dan harapan itu ditolak mentah-mentah oleh Soeharto, berdasarkan suratnya kepada Prawoto Mangkusasmito tanggal 6 Januari 1967. Meskipun usaha merehabilitasi bulan bintang tidak disetujui, pada tanggal 7 Mei 1967 ditandatangani deklarasi pembentukan Partai Muslimin Indonesia (Parmusi) yang didukung oleh 16 organisasi massa Islam ${ }^{1}$ yang tergabung dalam Badan Koordinasi Amal Muslimin (BKAM) (Hoeve, 1997: 83-84).

Pada tanggal 6 Februari 1968 terbentuk Panitia 7 (Komisi Pembentukan Parmusi) terdiri dari KH Faqih Usman sebagai ketua, Agus Sudono sebagai sekretaris dengan anggota Hasan Basri, Anwar Harjono, E.Z Muttaqien, Marzuki Yatim, dan Sjamsurijal. Namun intervensi pemerintah Orde Baru dalam internal Parmusi, mulai terasa saat beredarnya telegram rahasia yang menolak terpilihnya Mr. Moh. Roem sebagai Ketua Umum Parmusi. Sebagai penggantinya Soeharto pun merestui terpilihnya H. Djarnawi Hadikusumo sebagai ketua dan Drs. Lukman Harun sebagai sekretaris umum Parmusi. Kedua tokoh ini, berasal dari Muhammadiyah.

Salah satu Kabupaten yang cepat menanggapi kelahiran Parmusi di pusat adalah Padang Pariaman, yang terbentuk tahun 1968. Pembentukan Parmusi Cabang Padang Pariaman diperkuat SK Pimpinan Partai Parmusi No. 214/1/1968 yang menetapkan Raisuddin Muchtar sebagai pimpinan Cabang Partai Muslimin Indonesia Cabang Padang Pariaman(SK PP Parmusi No. 214/1., Tanggal 29 Oktober 1968).

Dalam usaha pengembangan kepengurusan Parmusi Cabang Padang Pariaman sampai ke nagari-nagari pada masa itu sangat sulit. Pemerintah pusat, sedari awal sudah comitted menjadikan Golkar sebagai kendaraan politiknya, sehingga di tiap Daerah Tk. II, ditekankan upaya untuk menghadang arus partai-partai selain Golkar. Tekanan dan intervensi yang terusmenerus dilancarkan pemerintah, di samping itu ada Pelaksana Khusus Daerah (Laksusda). Selain itu, sebab sulitnya Parmusi berkembang masa itu, dipicu trauma pada peristiwa PRRI yang melibatkan tokoh-tokoh Masyumi (Zed, Utama, Chaniago, 1996).

Inilah sisi menarik kajian Parmusi sebagai salah satu partai politik Islam yang hadir di Padang Pariaman pada awal Orde Baru. Parmusi, baik di tingkat pusat maupun di Padang Pariaman, tidak luput dari intrik dan permainan politik kotor pemerintah. Untuk menjabarkan tulisan ini lebih lanjut, ada beberapa item pertanyaan yang bisa diajukan. Bagaimana kebijakan pemerintah Orde Baru terhadap partai politik? Bagaimanaproses lahirnya Parmusi di tingkat pusat hingga ke Padang Pariaman? Bagaimana kiprah Parmusi Padang Pariaman pada masa Pemilu 1971? Seluruh item pertanyaan di atas, akan dijabarkan secara elaboratif pada bagian-bagian berikutnya.

Tulisan mengenai "Bulan Bintang di Bawah Kuasa Beringin: Parmusi Padang Pariaman Masa Orde Baru" berhubungan dengan konsep partai politik dan intimidasi politik. Partai politik adalah organisasi politik yang menjalankan ideologi tertentu atau dibentuk dengan tujuan khusus. Bisa juga didefinisikan, perkumpulan (segolongan orang-orang) yang seasas,

${ }^{1}$ Delapan belas organisasi Islam yang dimaksud adalah Muhammadiyah, Persis, Al-Irsyad, Gasbindo, KBIM, Jamiatul Wasliyah, Persatuan Islam, Nahdlatul Wathan, Matlaul Anwar, SNII, KBIM, PUI, AlIttihadiyah, PORBISI, PGAIRI, HSBI, PITI, Al-Irsyad, Wanita Islam (Mintaredja, 1968: 2). 
sehaluan, setujuan di bidang politik (Budiardjo, 1989: 159). Baik yang berdasarkan partai kader atau struktur kepartaian yang dimonopoli oleh sekelompok anggota partai yang terkemuka. Atau bisa juga berdasarkan partai massa, yaitu partai politik yang mengutamakan kekuatan berdasarkan keunggulan jumlah anggotanya (Kartz and Crotty, 2006).

Intimidasi politik bisa diartikan sebagai perilaku agresif yang disengaja, untuk membuat tekanan kepada seseorang, kelompok, ataupun masyarakat secara fisik maupun psikologis (Tanter and Young, 1993). Intimidasi bisa juga didefenisikan tindakan untuk memaksa orang lain untuk berbuat sesuatu, dimana pelaku mendapatkan manfaat dari tindakan itu. Bila dihubungkan dengan persoalan yang pernah terjadi diinternal Parmusi Padang Pariaman, konsep intimidasi politik, 'dimainkan' oleh negara melalui lembaga-lembanganya, salah satunya Pelaksana Khusus Daerah (Laksusda) dan birokrasi pemerintahan.

Dalam studi terdahulu, sudah banyak yang menulis tentang partai politik, namun yang khusus menulis tentang Partai Muslimin Indonesia (Parmusi) Padang Pariaman, belum ada yang menulis. Lili Romli (2004: 29-48) dalam Partai Islam dan Pemilih Islam di Indonesia menguraikan tentang kecendrungan munculnya partai-partai pada masa reformasiyang cendrung menggunakan asas Islam, bukan Pancasila. Dalam tulisannya Lili menguraikan tentang pertumbuhan partai politik pada masa Orde Baru, sampai munculnya kebijakan fusi partai politik, deideologisasi, massa mengambang, dan asas tunggal Pancasila. Namun, dalam tulisannya Lili tidak membahas keberadaan Parmusi Padang Pariaman.

Muh. Fatkhan (2010) dalam Dinamika Islam Pada Masa Orde Baru, membahas mengenai gerakan Islam sejak masa pra kemerdekaan hingga menuju masa Orba. Dalam tulisannya, Fatkhan melihat hadirnya Parmusi pada masa awal Orba merupakan bagian dari restrukturisasi politik. Jalan ini menurut Fatkhan sebagai jalan tengah dari pilihan politik Orba, untuk menampung aspirasi dari pemilih Islam modernis -yang direpresentasikan sebagai Partai Masyumi. Namun, dalam tulisannya Fatkhan tidak ada menyinggung hadirnya Parmusi di Padang Pariaman.

Kiki Mikail (2015) dalam Pemilu dan Partai Politik di Indonesia. Menanti Kebangkitan Partai Politik di Tahun 2019. Dalam tulisannya, Kiki menguraikan kecendrungan naiknya suara partai Islam pada Pemilu 2014, dibandingkan dengan Pemilu tahun 2009, yang lebih rendah dari partai nasionalis. Kiki menganalisis kasus-kasus yang menimpa politisi muslim, baik dari kalangan partai beriodeologi nasional, maupun agama, rupanya tidak langsung berimbas kepada turunnya kecendrungan dalam menentukan pilihan politiknya.Dari ketiga jurnal yang ada, tidak satupun yang menyinggung hadirnya Parmusi di Padang Pariaman.

\section{Metodologi Penelitian}

Tulisan Parmusi Padang Pariaman Masa Orde Baru disusun berdasarkan metode penelitian sejarah (Kartodirdjo, 1983). Tahap pertama, adalah heuristik. Heuristik merupakan tahap pencarian dan pengumpulan sumber-sumber sejarah. Sumber yang digunakan dalam tulisan ini berupa sumber tertulisdansumber lisan. Sumber-sumber tertulis meliputi arsip baik yang diproduksi oleh pemerintah kolonial Belanda maupun pemerintah Indonesia. Sumbersumber itu antara lainterdapat di Arsip Nasional Indonesia dan koleksi pribadi Alhadar Alam.

Tahap kedua adalah kritik sumber, yang dapat dibagi atas kritik ekstern dan intern. Kritik ekstern dilakukan untuk mencari otentisitas arsip dan dokumen yang sudah didapatkan. Sedangkan kritik intern dilakukan terhadap isi dokumen yang otentik tersebut untuk mendapat kevalidan data yang dikandungnya. Kritik ekstern terhadap sumber-sumber yang diperoleh, baik arsip, majalah, dan lain sebagainya.

Tahap ketiga adalah analisis dan sintesis data (interpretasi). Fakta yang diperoleh, baik dari sumber tertulis maupun sumber lisan dianalisis dengan menggunakan analisis prosesual 
dan struktural. (Lloyd 1993). Analisis prosesual digunakan guna menemukan perkembangan Parmusiyang bertahan ditengah intimidasi politik Orde Baru. Analisis struktural digunakan untuk menganalisis kebijakan-kebijakan yang dikeluarkan pemerintah Orde Baru, terutama terhadap pers yang dianggap membahayakan tatanan masyarakat dan negara. Tahap keempat yaitu tahap penulisan (historiografi) (Kuntowijoyo, 2003).

\section{Hasil dan Pembahasan}

\section{Awal Lahirnya Orde Baru}

Keberhasilan Jenderal Soeharto sebagai pengemban Supersemar yang dilanjutkan dengan pelantikannya sebagai Pejabat Presiden dalam Sidang MPRS bulan Maret 1967, menandai akhir dari Demokrasi Terpimpin di Indonesia. Sementara itu, parpol belum dapat bergerak leluasa setelah dilumpuhkan Soekarno. Dalam kondisi seperti itu, ABRI merupakan satu-satunya kekuatan yang mampu berbuat apa saja. ${ }^{2}$

Orde Baru merupakan rezim yang secara formal lahir pada tanggal 12 Maret 1967 dan secara prematur telah menumbuhkan dirinya sejak keluarnya Surat Perintah 11 Maret 1966. Dewi Fortuna Anwar (1985: 6-7) memandang Orde Baru sebagai bentuk koalisi militer dengan teknokrat sangat menentukan corak pembangunan nasional, di samping lima pilar utama, di antaranya struktur politik Orba yang mempunyai ciri patrimonial, birokrasi tanpa golongan, dikuasai sepenuhnya oleh militer, ${ }^{3}$ penekanan pada ketertiban dan stabilitas keamanan, dan pengembangan ekonomi kapitalis yang digerakkan dengan bantuan pinjaman luar negeri.

Setelah berhasil menghancurkan kekuatan Komunis, pemerintah Orde Baru secara simultan mengukuhkan kekuasaannya di panggung politik. Hal ini terlihat bagaimana Orde Baru mendefenisikan dirinya berbeda dengan Orde Lama (Moertopo, 1982: 20). Setelah mengidentifikasi dirinya dengan empat karak-teristik ini, Orde Baru memberi prioritas pada pelaksanaan pembangunan dan modernisasi, khususnya kehidupan ekonomi dan pertanian untuk meningkatkan kesejahteraan rakyat. Didukung oleh ABRI dan sejumlah teknokrat yang terkenal, Orde Baru berupaya memperbaiki kondisi ekonomi yang hancur pada masa Demokrasi Terpimpin.

Lebih jauh, prestasi ekonomi ini dianggap berguna dalam mengefektifkan kekuasaan militer, terutama melegetimasi kekuasaan Orde Baru. Dalam upaya menciptakan stabilitas politik dan ekonomi, Orde Baru mencanangkan pelaksanaan Pembangunan Lima Tahun(Pelita) secara berkesinambungan, seperti yang diamanatkan dalam Garis garis Besar Haluan Negara (GBHN) sejak 1 April 1969.

Terlepas dari prestasi ekonomi yang dicapai pemerintah Orde Baru, juga diikuti pengendalian pemerintah terhadap kehidupan sosial politik. Penegasan mengenai stabilitas politik ini menurut Eep Saefulloh Fatah (1994: 20-75) dimulai dengan penghancuran musuh negara yang secara historis bisa menjadi potensi memusuhi dan merongrong kewibawaan Orde Baru. Kelompok ini terdiri dari kekuatan loyalis Soekarno, kekuatan Komunis, Kelompok PSI, dan kelompok Masyumi.

2. Proses Berdirinya Parmusi

Pada awal Orde Baru, eks pendukung Masyumi yang berjasa menumbangkan Demokrasi Terpimpin, berharap merehabilitasi Masyumi yang diberangus oleh Soekarno

\footnotetext{
${ }^{2}$ Menurut Alfian, meskipun merupakan satu-satunya kekuatan yang tersisapada masa Orde Lama, ABRI tidak membentuk pemerintahan Junta Militer. Hal ini disebabkan sejak awal dalam tubuh ABRI telah berkembang ideologi anti oligarkhi militer (Alfian, 1978: 4-5).

${ }^{3}$ Menurut Dawam Rahardjo dukungan sistem partai-partai pada masa Orba praktis digantikan oleh sistem negara korporasi yang berintikanorganisasimiliter, sehingga tidak berlebihan jika dikatakan organisasi militer adalah suatu kekuatan yang paling kongkrit yang sekaligusmerupakan wilayah birokrasi tersendiri dalam birokrasi Negara yang berada di luarkontrol (Raharjo, 1983: 4-6).
}

Jurnal Socius: Journal of Sociology Research and Education Vol. 4, No.2, Th. 2017 
(Mintaredja, 1968:1). Namun usulan itu ditolak mentah-mentah oleh Soeharto. Adapun alasan Soeharto menolak merehabilitasi, karena Masyumi tidak terlepas dari peristiwaperistiwa sebagai hasil konflik antara Pusat dan daerah, atau yang dikenal dengan Pemerintah Revolusioner Republik Indonesia (Haris, 1991: 6). Gagalnya usaha merehabilitasi Masyumi, menyebabkan pendukung utama partai tersebut merumuskan nama parpol yang baru, Pada tanggal 7 Mei 1967 ditandatangani deklarasi pembentukan Partai Muslimin Indonesia (Parmusi) yang didukung oleh 16 organisasi massa Islam (Anggaran Dasar Partai Muslimin Indonesia, 1968)yang tergabung dalam Badan Koordinasi Amal Muslimin (BKAM). ${ }^{4}$ Sebagai partai politik yang berasas Islam, Parmusi menegaskan dalam Pasal 2 tentang asas dan tujuan partai:

1. Azas Partai ialah Islam

2. Tudjuan Partai ialah bersama ${ }^{2}$ dengan semua golongan warga negara jang ber-Ketuhanan Jang Maha Esa menegakkan dan membangun Negara Republik Indonesia atas landasan Pantjasila dan Undang ${ }^{2}$ Dasar 1945 menudju masjarakat adil dan makmur jang diridhai Allah s.w.t. (Anggaran Dasar Partai Muslimin Indonesia, 1968).

Pada tanggal 5 Februari 1968 Presiden Soeharto menerima pimpinan Partai Muslimin Indonesia di istana negara. Adapun alasan Soeharto merestui rencana pendirian Parmusi adalah pengakuannya terhadap keberadaan ormas-ormas Islam yang belum berafiliasi dengan salah satu parpol Islam yang jumlah pengikutnya sama besarnya dengan pengikut Partai Masyumi. Namun dalam pertemuan itu, Presiden Soeharto melarang eks pimpinan Masyumi masuk dalam stuktur Parmusi.Larangan masuknya bekas pimpinan Masyumi dalam struktur Parmusi, dapat dipahami sebagai phobia dari pemerintah Orba terhadap bangkitnya kembali peranan Islam di pentas nasional. Selain itu, pemerintah Orba juga cemas dengan besarnya pengaruh eks tokoh Masyumi, seperti M. Natsir, Burhanuddin Harahap, Prawoto Mangkusasmito, Anwar Harjono dan lainnya dalam menggalang kekuatan umat Islam. Meskipun pemerintah meminta bekas pimpinan Masyumi untuk tidak dimasukan dalam struktur kepengurusan, namun Muktamar I Parmusi tanggal 2-7 November 1968 di Malang tetap memasukan nama-nama bekas pimpinan Masyumi, seperti Mr. Moh. Roem (Ketua Umum) dan Dr. Anwar Harjono, SH (Ketua I). (Keputusan Ke-I Partai Muslimin Indonesia di Malang tanggal 2-7 November 1968).

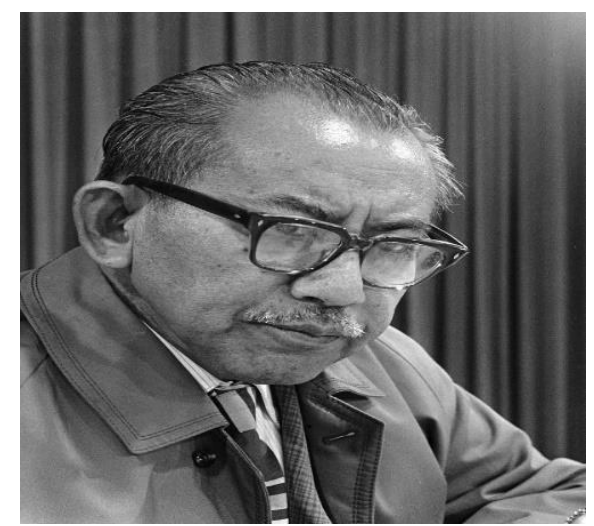

Gambar 1. Mr. Moh. Roem, ketua pertama Parmusi yang terpilih dalam Muktamar I di Malang. Namun, tiba-tiba dikudeta lewat telegram rahasia Presiden Soeharto

Sumber: Direpro dari Koleksi Pribadi Alhadar Alam.

\footnotetext{
${ }^{4}$ Keenambelas organisasi massa Islam yang mendukung terbentuknya Parmusi ditegaskan dalam Piagam Partai Muslimin Indonesia: Muhammadiyah, Al-Jamiyatul Washliyah, GASBINDO, Persatuan Islam, Nahdatul Wathan, SNII, KBIM, Persatuan Umat Islam, Al-Ittihadiyah, PORBISI, PGAIRI, HSBI, PITI, Al-Irsyad, danWanita Islam (Daftar Nama Ormas Pendukung dalam Piagam Partai Muslimin Indonesia tanggal 17 Agustus 1967).
}

Jurnal Socins: Journal of Sociology Research and Education Vol. 4, No.2, Th. 2017 
Intervensi pemerintah Orba dalam masalah internal Parmusi, kemudian semakin nyata setelah keluarnya telegram rahasia yang ditujukan kepada pimpinan Parmusi. Isi telegram itu antara lain, menolak terpilihnya Mr. Moh. Roem sebagai Ketua Umum Parmusi. Sebagai penggantinya Soeharto merestui terpilihnya H. Djarnawi Hadikusumo sebagai Ketua dan Drs. Lukman Harun sebagai Sekretaris Umum Parmusi. Sedangkan pengakuan berdirinya Parmusi ditetapkan dalam Keputusan Presiden No.70 Tahun 1968. Di dalam SK Presiden tersebut disebutkan bahwa Parmusi merupakan penggabungan dari organisasi masyarakat Islam (Keputusan Presiden Republik Indonesia No.70 Tahun 1968).

Meskipun beberapa nama bekas pimpinan Masyumi telah dilarang masuk dalam struktur partai, namun beberapa pimpinan Parmusi tetap meminta dukungan mereka. Hal ini terbukti dengan tampilnya M. Natsir sebagai pembuka Konferensi Parmusi Cabang Krawang tanggal 28 Juli 1970. (RB. Khatib Pahlwan Kayo, wawancara tanggal 1 Desember 2017). Maka sejak perkembangannya di tingkat pusat, maka Parmusi pun menyebar ke setiap wilayahRepublik Indonesia, termasuk di Sumatera Barat dan Padang Pariaman.

Sejak lahirnya Parmusi Sumatera Barat, berdirilah cabang-cabang yang berkedudukan di setiap kotamadya dan kabupaten. Parmusi Cabang Padang Pariaman didirikan pada tahun 1968, berdasarkan Surat Keputusan Nomor: 214/1.- tanggal 29 Oktober 1968. Sementara susunan pengurus Parmusi Padang Pariaman ditetapkan sebagai berikut (SK Pimpinan Partai "Partai Muslimin Indonesia" Nomor 214/1/29-68).

Ketua

Wakil Ketua

Wakil Ketua

Wakil Ketua

Sekretaris

Wakil Sekretaris
:Drs. Raisuddin Muchtar

: Chairoel Moenir

: St.Lazran Aminullah

: Ramli A.D

: Hasan Basri Amir, BA

\section{Intervensi Pemerintah dalam Parmusi Cabang Padang Pariaman}

Lahirnya Parmusi Cabang Padang Pariaman yang sebelumnya banyak ditunggu-tunggu oleh bekas politisi Masyumi, ternyata tidak dapatberbuat banyak. Kondisi ini disebabkan lambannya pimpinan partai dalam mengembangkan Parmusi, baik di tingkat kecamatan ataupun nagari. Pada masa awal pembentukannya, struktur Parmusi Cabang Padang Pariaman didominasi eks aktivis Masyumi, seperti Kasim Munafy, St Aliasar, Marna Syafrida, M. DJ. Dt. Bungsu, dan Tharuddin (Alhadar Alam, t.t: 1).

Pasca terbentuknya Parmusi, beberapa orang pengurus mulai melontarkan kritik pedas terhadap kebijakan pemerintah Orba, terutama dalam persoalan menganakemaskan Golkar. Kritikan itu bersifat mendiskreditkan, dilakukan di tempat umum. "Biasanya mereka-mereka yang mengkritik negatif terhadap pemerintah Orba ini siang hari berkumpul tiap hari di toko Ahmad Zaini, yang terletak dekat jembatan arah Pasar Pariaman.", demikian tulis Alhadar (t.t: 2) dalam manuskripnya.

Pengurus Parmusi yang sering mengkritik itu, tidak menyadari bahwa pemerintah melalui intel dan Pelaksana Khusus Daerah (Laksusda), mengintai gerak-gerik mereka. ${ }^{5}$ Tidak mengherankan, jika pemerintah mempersulit jalannya Parmusi dengan menghalangi aktivitas partai, di antaranya menye-lenggarakan rapat harus seizin pihak Polres, menempatkan intel dari Polres Pariaman setiap kali berlangsungnya rapat-rapat Parmusi.

Dipersulitnya gerak Cabang Padang Pariaman, menyebabkan pengurusnya jenuh dan menarik diri keluar dari Parmusi. Untuk mengembalikan gairah berpolitik, keluarga Bulan Bintang (bekas anggota Masyumi) mengkonsolidasi pertemuan. Konsolidasi ini

${ }^{5}$ Laksusda merupakan lembaga yang berada di bawah Angkatan Darat yang tersebar diseluruh Indonesia yang bertugasuntuk men-screaning calon-calon legislatif yang mengajukan diri dalam Pemilu (Alhadar, tt: 4).

Jurnal Socins: Journal of Sociology Research and Education Vol. 4, No.2, Th. 2017 
ditindaklanjuti dengan pertemuan tanggal 30 Maret 1970 di Masjid Taratak Pariaman (Chairuman Isa, wawancara tanggal 1 Januari 2018).

Rapat yang dihadiri 150 orang peserta, terdiri dari tokoh-tokoh masyarakat Pariaman, termasuk dari tiga kecamatan Padang Luar Kota (Koto Tangah, Pauh IX, dan Lubuk Begalung). Selain itu, rapat juga dihadiri pimpinan Muhamma-diyah Padang Pariaman dan eks tokoh Masyumi. Berdasarkan hasil keputusan rapat itu, terpilihlah Nurmal Said sebagai Ketua Parmusi Padang Pariaman. Keputusan rapat di Masjid Taratak, selanjutnya diperkuat melalui SK Pimpinan wilayah Parmusi Sumatera Barat No.093/C/1-70tanggal 30 Maret 1970.

Pada masa kepemimpinan Nurmal Said, seluruh aktivitas partai diselengga-rakan dengan baik. Bahkan pengurus Parmusi Padang Pariaman secara simultan turun ke nagarinagari untuk menggalang simpatisan dan dukungan masyarakat. Kebijakan ini diambil oleh pengurus partai, mengingat proses pendirian Parmusi hanya sampai di daerah tingkat II, berbeda dengan Golongan Karya yang terbentuk hingga ke desa-desa. (Chairuman Isa, wawancara tanggal 1 Januari 2018). Namun kepemimpinan Nurmal Said hanya bertahan sekitar enam bulan, setelah kepemimpinannya di-reshuffle karena statusnya sebagai Pegawai Negeri Sipil (PNS). ${ }^{6}$ Nurmal Said akhirnya mengundurkan diri, setelah beredarnya Peraturan Pemerintah No. 6 tanggal 30 Maret 1970.

Untuk mengatasi kekosongan jabatan Ketua Parmusi Padang Pariaman, diadakanlah Konferensi Cabang. Berdasarkan hasil konferensi diputuskan Alhadar Alam terpilih sebagai Ketua Parmusi Padang Pariaman untuk periode 1970-1971. Susunan kepengurusan Parmusi Padang Pariaman, ditetapkan melalui SK No.249/K.U./71 tanggal 16 Maret 1971 (SK PP Parmusi No.249/K.U./71 tanggal 16 Maret 1971). Seperti halnya Nurmal Said, Alhadar Alam juga berstatus sebagai PNS di SMEA Pariaman. Alhadar awalnya ragu terhadap amanah yang diberikan kepadanya. Namun berkat dukungan yang diberikan Kolonel Moh. Nur (Bupati Padang Pariaman), ia pun memantapkan hatinya untuk terus beraktivitas di partai, meskipun berstatus PNS.

"Bupati waktu itu memberi jaminan kepada Saya untuk terus memimpin Parmusi. Bupati meminta Saya untuk tenang dan diam dengan edaran adanya PP No.6 tahun 1970." (Alhadar, $\mathrm{tt}: 5)$.

Pada masa kepemimpinan Alhadar Alam, kebijakan Parmusi mulai diarahkan pada persiapan Pemilu yang dilaksanakan tahun 1971. Pengurus Parmusi masa itu, sering mengadakan lawatan ke berbagai nagari, guna meraih simpati yang tujuan akhirnya adalah mendulang suara sebanyak-banyaknya pada Pemilu 1971. Alhadar Alam menyadari setiap kali acara kunjungan partai, maupun rapat konsolidasi di Kantor Parmusi sering diikuti intel dari Polres Pariaman.

Untuk membiayai administrasi Parmusi Padang Pariaman, umumnya berasal dari pembiayaan anggota partai dan simpatisan. Berbeda halnya dengan Golkar yang mendapat dana besar dari pemerintah guna memperluas jaringan politiknya ke tingkat pedesaan. Minimnya dana partai terlihat saat Pimpinan Cabang Parmusi Padang Pariaman menjelaskan minimnya perkakas administrasi, contohnya mesin ketik.

"Dalam melantjarkan perdjuangan kita, kami Pimpinan Tjabang mengalami kesulitan peralatan. Diantaranja ketiadaan mesin tulis. Mesin tulis ini dirasakan sjarat mutlak adanja. Kami mengusahakan hendak membeli sebuah mesin tulis seharga Rp 30.000,- Dari uang bantuan untuk pemilu dapat kita harapkan untuk membeli mesin ini sebanjak Rp 15.000,Diwaktu pelantikan Pimpinan Tjabang tempo hari sudah ada Anak2 Tjabang yang telah bersedia memberikan sumbangan untuk membeli mesin ini sebagaimana terlampir..."

${ }^{6}$ Pengunduran diri Nurmal Said, menurut Alhadar Alam karena status PNS-nya dan tercatat sebagai dosen pada Universitas Andalas Padang (Chairuman Isa, wawancara tanggal 1 Januari 2018).

Jurnal Socius: Journal of Sociology Research and Education Vol. 4, No.2, Th. 2017 
(Instruksi Kepada Pimpinan Anak Tjabang Partai Muslimin Indonesia dalam Daerah Kabupaten Padang Pariaman tanggal 20 Djanuari 1971, 1).

\section{Kiprah Parmusi Padang Pariaman dalam Pemilu 1971}

Sebagai upaya meraih massa simpatisan menjelang Pemilu 1971, Parmusi Padang Pariaman berusaha menggalang kekuatan sebagai program lanjutan yang pernah dirintis Nurmal Said. Namun, Alhadar Alam mengakui, dalam usaha pengembangan partai, tidak seluruh kecamatanterbentuk kepengurusannya. Selain itu, tindakan intervensi Laksusda pada masyarakat di nagari-nagari semakin nyata, salah satunya dengan menjelek-jelekan Parmusi.

Intervensi pemerintah terhadap partai politik tidak sebatas itu. Intervensi juga diarahkan kepada anggota partai dan calon legislatif, sehingga banyak anggota Parmusi yang telah bergabung, kemudian keluar dan menyerahkan surat pengunduran diri. Sedangkan wilayah yang sulit dipengaruhi adalah Kecamatan VII Koto/Sungai Sarik. Hal ini dapat dimaklumi karena wilayah Sungai Sarik dulunya merupakan basis Partai Komunis Indonesia (PKI).

Dalam rangka menghadapi pemilu, Corps Pemilih (bagian dari sistem perekrutan calon legistlatif Parmusi) mulai menjalankan fungsinya, yakni merekrut bakal calon legislatif. Dari hasil perekrutan itu, dibuatlah daftar calon Parmusi Padang Pariaman, yang selanjutnya diserahkan kepada Laksusda (Daf-tar Tjalon Partai Muslimin Indonesia Tjabang Padang Pariaman untuk Daerah Tk.II Pd/Prm tanggal 13 Januari 1971).

Namun beberapa nama caleg Parmusi, kemudian dicoret Laksusda dengan alasan beberapa nama dicurigai tokoh eks Masyumi. Peristiwa pencoretan caleg Parmusi terjadi dalam rapat Laksusda yang dihadiri oleh ketua-ketua partai dan Golkar. Menurut Chairuman Isa, 14 nama bakal caleg Parmusi dicoret pihak Laksusda. Sebagai konsekuensinya pimpinan Parmusi Padang Pariaman harus menyerahkan kembali daftar calon tambahan.

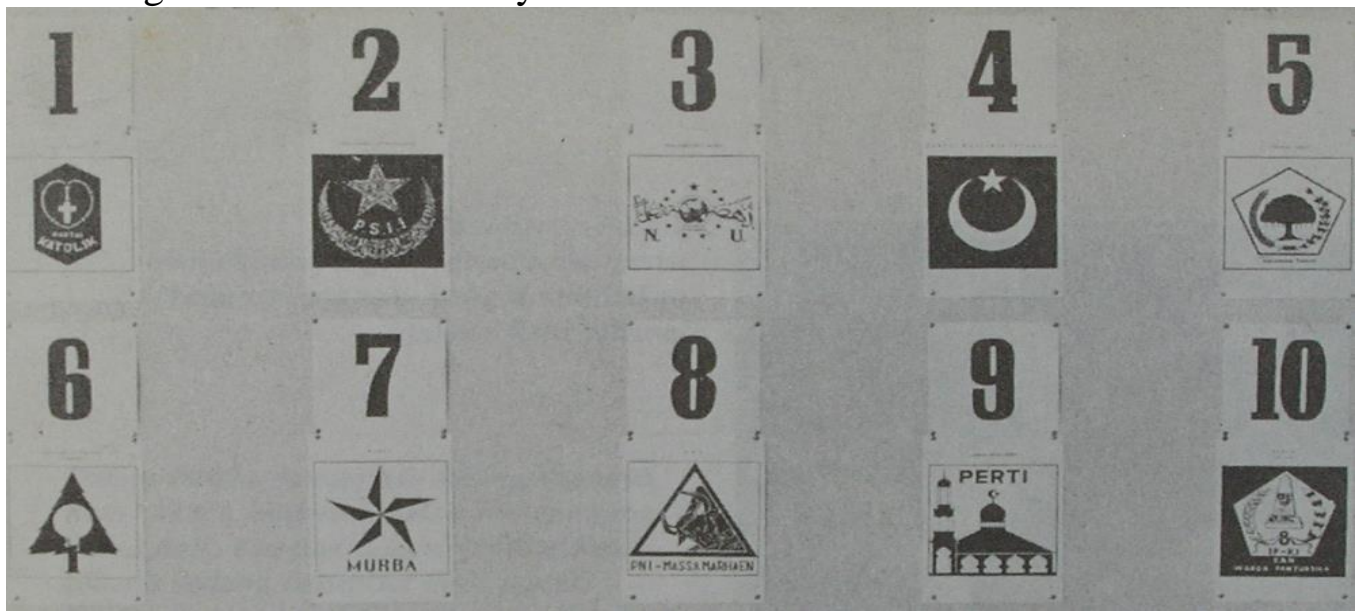

Gambar 2. Kontestan partai politik dalam Pemilu 1971. Pada masa itu, Parmusi merupakan kontestan no.4.

Sumber: Direpro dari Koleksi Pribadi Alhadar Alam.

"Hal ini yang paling memusingkan saya sebagai KetuaPartai waktu itu adalah calon dari Pauh yang tidak dapat jadi calon tetap karena dicoret oleh Laksusda. Padahal Kecamatan Pauh adalah basis Parmusi... Sebagaimana tadi saya katakan bahwa pengumuman Laksusda Jumat malam dan Sabtu besoknya Salat Idul Adha tidak dapat diganti lagi. Padahal waktu perhubungan/transpor amat sulit." (Instruksi Kepada Pimpinan Anak Tjabang Partai Muslimin Indonesia dalam Daerah Kabupaten Padang Pariaman tanggal 20 Djanuari 1971, 2).

Setelah daftar caleg yang diminta tidak terpenuhi, pihak Laksusda menetapkan calon tetap legislatif yang sebelumnya berjumlah 34 orang menjadi 20 orang caleg. Adapun namanama calegnya adalah: Alhadar Alam (Pariaman), Chairuddin (Kudu), Hasan Yunus 
(Sikapak), Syafri Jauhari (Naras), Nazaruddin (Naras), Masna S (Rawang), Rostina Thaib (Lubuk Alung), Nazar Afir (Lubuk Begalung), Abdul Aziz (Koto Tangah, Padang Luar Kota), Djamal Manaf (Pauh V), Amir Thaib (Koto Tinggi), Abdul Jalil (Sungai Rotan), Hindun Sahih (Pauh), Arifin Tanjung (Kuraitaji), Djamanis Umar (Koto Tangah, Padang Luar Kota), Anizar Kindin (Paingan Pariaman), Marhini Madjid (Padusunan), Amir Zakaria (Koto Tinggi), dan Buchari Abu (Koto Tinggi) (Alhadar: 6).

Menjelang Pemilu 1971, koordinasi di antara pengurus Parmusi Padang Pariaman makin diintensifkan. Rapat-rapat anggota biasanya diadakan di rumah Alhadar Alam yang sekaligus berfungsi sebagai Kantor DPC Parmusi Padang Pariaman. Sebelum rapat diadakan, terlebih dulu harus melaporkan tujuan kegiatan pada Polres Padang Pariaman. Jika rapat itu dihadiri oleh intel Polres, biasanya materi yang disampaikan adalah laporan kegiatan dan kunjungan daerah. Namun jika menyangkut masalah internal partai, konsolidasi, upaya pemenangan Pemilu biasanya dalam pertemuan sehari-hari tanpa melibatkan banyak anggota partai.

Meskipun Parmusi Padang Pariaman sering mendapat intervensi Laksusda, namun pimpinan partai tetap menjalin hubungan baik. Bahkan dengan kalangan kepolisian hubungan baik selalu dijaga, dengan melaporkan setiap kegiatan rapat Parmusi. Hasilnya berdampak positif, terutama masa putaran kampanye. Sehingga jadwal kampanye Parmusi tidak pernah ditukar atau dialihkan dengan partai politik yang lain.

Sebelum pelaksanaan kampanye terbuka, Pimpinan Parmusi Padang Pariaman kembali mengingatkan kepada seluruh jajaran anggota partai tidak mengeluarkan statement politik tanpa seizin atau sepengetahuan ketua partai. Tujuannya untuk menjauhkan partai dari kesulitan-kesulitan yang dapat ditimbul-kan oleh pernyataan politik itu.

Sebagai pimpinan, Alhadar Alammengingatkan pengurus partai untuk menjauhkan sifat yang dapat memecah belah persatuan, dan ambisi pribadi. Demikian halnya dalam pergaulan. Pimpinan maupun anggota partai diminta mengembangkan sikap saling hormatmenghormati. Artinya, anak muda harus menghormati yang tua, yang tua harus menyayangi yang muda. Di samping itu, pimpinan partai kembali mengingatkan penyerahan laporanlaporan yang berkenaan dengan keadaan atau kejadian-kejadian di daerah (Alhadar, t.t: 6).

Sementara masa kampanye terbuka di Padang Pariaman dimulai tanggal 27 April 1971 (Hasan Yunus, wawancara tanggal 2 Januari 2017). Tidak jauh berbeda dengan daerah lain, di Kabupaten Padang Pariaman terjadi persaingan antara Golkar dan Parmusi. Pada hari pertama kampanye, kegiatan parpol lebih terarah pada penempelan tanda gambar. Pada hari pertama itu, lebih didominasi "pohon beringin", seperti di warung-warung, pagar rumah, dan di dinding rumah. Pada hari kedua, barulah muncul gambar bulan sabit dan bintang (Parmusi), bola dunia (NU), bulan bintang (PSII), bintang (Murba), dan masjid menara (Perti).

Golkar sebagai mesin pemenang Orde Baru berupaya keras menunjukkan superioritasnya di Pariaman. Tanggal 9 Juni 1971 Golkar mendatangkan juru kampanye (jurkam) pusat Ali Moertopo yang masa itu menjabat Ketua Badan Pengendali Pemilu (BAPPILU). Sedangkan lawan politik mereka, dilarang mendatangkan jurkam dari Dewan Pimpinan Pusat (DPP). Meskipun terjadi diskriminasi dalam pembagian jadwal kampanye, pimpinan Parmusi Padang Pariaman tidak mendapat rintangan berarti, sebab telah menjalin hubungan erat dengan pihak kepolisian. Sehingga jadwal kampanye mereka relatif aman, dibandingkan kampanye Perti, PSII, NU, dan PNI.

Menjelang akhir kampanye terbuka, pemerintah kembali mengintervensi Parmusi Padang Pariaman. Adapun strategi yang dilancarkan antara lain, jika jadwal kampanye Parmusi dilaksanakan esok hari, aparat nagari dikerahkan untuk mengingatkan warganya melaksanakan gotong royong. Akibatnya beberapa orang yang awalnya berniat ikut kampanye, harus mengikuti gotong-royong. 
Berbagai cara dan taktik kotor yang dilancarkan pihak pemerintah dan Laksusda, namun tidak memudarkan semangat jajaran pimpinan Parmusi Cabang Padang Pariaman. Seperti Alhadar yang tetap berkampanye ke berbagai nagari di Padang Pariaman. Dalam waktu dua bulan masa kampanye, Parmusi Padang Pariaman melakukan kampanye sebanyak empat puluh kali (Fuadi Jalil, wawancara tanggal 2 Januari 2017).

Meskipun tekadnya kuat untuk terjun di pentas politik, intrik dan ancaman tetap dilancarkan pemerintah terhadap Alhadar Alam. Menjelang dua hari pelaksanaan Pemilu, tepatnya tanggal 1 Juli 1971, Alhadar didatangi tiga utusan PGRI, yakni Ali Amran, Ali Hasan, dan Muchlis. Mereka meminta Alhadar untuk mundur dari Parmusi dan aktif kembali sebagai guru (Hasan Yunus, wawancara tanggal 2 Januari 2017). Namun keinginan ketiga orang itu ditolak Alhadar, dengan alasan telah dekatnya masa Pemilu 1971.

Pada tanggal 3 Juli 1971 pemilu pertama masa Orde Baru di Padang Pariaman, diwarnai sejumlah kecurangan. Seperti kecurangan yang dilakukan petugas TPS di Kampung Pondok (Chairuman Isa, wawancara tanggal 1 Januari 2017). Setelah diadakan penghitungan ulang, ternyata suara Parmusi semakin bertambah, meskipun jumlahnya belum mengalahkan raihan suara Golkar.

Tindak curang lain yang dilakukan oleh petugas TPS, antara lain dengan merusak kertas suara. Misalnya dengan mencoblos dua kali, merusak kertas suara dengan kuku. Meskipun ada sejumlah temuan di TPS, namun tidak pernah mendapat tanggapan dari Panitia Pemilihan Indonesia. Berikut hasil Pemilu 1971 di Padang Pariaman:

Tabel 1. Perolehan Hasil Suara Pemilu 1971 Per Kecamatan Kabupaten Padang Pariaman

\begin{tabular}{|c|c|c|c|c|c|c|c|c|c|c|}
\hline Kecamatan & PSII & $\mathbf{N U}$ & Perti & $\begin{array}{l}\text { Par } \\
\text { musi }\end{array}$ & IPKI & Golkar & $\begin{array}{l}\text { Kat } \\
\text { olik }\end{array}$ & $\begin{array}{c}\text { Parkin } \\
\text { do }\end{array}$ & $\underset{\text { ba }}{\text { Mur }}$ & PNI \\
\hline $\begin{array}{l}\text { Sei } \\
\text { Geringging }\end{array}$ & 87 & 767 & 4008 & 1306 & 963 & 9717 & 2 & 20 & 7 & 104 \\
\hline Sei Limau & 83 & 2016 & 1591 & 3772 & 681 & 9244 & 4 & 14 & 6 & 14 \\
\hline $\begin{array}{l}\text { V Koto } \\
\text { Kp.Dalam }\end{array}$ & 170 & 551 & 823 & 3394 & 135 & 11254 & 4 & 9 & 7 & 19 \\
\hline Pariaman & 276 & 1811 & 746 & 7801 & 66 & 8434 & 6 & 13 & 15 & 37 \\
\hline Nan Sabaris & 875 & 3810 & 574 & 4927 & 44 & 10479 & 6 & 89 & 8 & 41 \\
\hline VIII Koto & 350 & 467 & 653 & 520 & 130 & 16225 & 3 & 22 & 117 & 110 \\
\hline $\begin{array}{l}2 \times 11 \text { enam } \\
\text { lingkung }\end{array}$ & 104 & 2255 & 1215 & 1559 & 58 & 10540 & 9 & 19 & 14 & 79 \\
\hline $\begin{array}{l}\text { Lubuk } \\
\text { Alung }\end{array}$ & 225 & 1948 & 330 & 2283 & 142 & 14178 & 50 & 141 & 46 & 342 \\
\hline Pauh & 70 & 584 & 3955 & 12180 & 119 & 4467 & 5 & 6 & 8 & 22 \\
\hline $\begin{array}{l}\text { Lubuk } \\
\text { Begalung }\end{array}$ & 133 & 513 & 5076 & 4663 & 105 & 12780 & 4 & 27 & 7 & 37 \\
\hline Mentawai & 11 & 43 & 37 & 179 & 34 & 6991 & 1502 & 5379 & 4 & 36 \\
\hline
\end{tabular}

Sumber: Arsip penghitungan hasil pemilu 1971 di Padang Pariaman

Setelah pelaksanaan Pemilu 1971, tepatnya tanggal 7 Oktober 1971 masing-masing anggota legislatif yang memperoleh kursi di Dewan Perwakilan Rakyat Daerah (DPRD) Tk.II Padang Pariaman dilantik, antara lain: Golkar memperoleh 18 kursi, Parmusi memperoleh 7 kursi, Perti memperoleh 3 kursi, NU memperoleh 2 kursi, PSII memperoleh 1 kursi. Sedangkan untuk TNI/Polri mendapat jatah 7 kursi. Setelah pelantikan anggota legislatif hasil Pemilu 1971, Alhadar Alam dipilih sebagai Wakil Ketua DPRD Tk. II Padang Pariaman, sedangkan posisi ketua dipegang oleh Djendar (Golkar). 


\section{Penutup}

Parmusi Cabang Padang Pariaman didirikan pada tahun 1968 dipimpin oleh Raisuddin Muchtar dan sekretarisnya Hasan Basri Amir. Dua tahun kemudian, Parmusi dirombak kepengurusannya pada tahun 1970 yang diketuai oleh Nurmal Said dan Sekretarisnya Zarlis Zakaria. Di bawah kepemimpinan Nurmal Said seluruh kegiatan kepartaian dapat diselenggarakan dengan baik. Bahkan pengurus Parmusi Padang Pariaman secara simultan turun ke desa-desa untuk menggalang simpatisan dan dukungan masyarakat.

Namun kepemimpinan Nurmal Said hanya bertahan sekitar enam bulan, setelah kepemimpinannya di-reshuffle karena statusnya sebagai Pegawai Negeri Sipil (PNS). Nurmal Said akhirnya memilih mengundurkan diri dari Parmusi setelah keluarnya Peraturan Pemerintah No. 6 tanggal 30 Maret 1970 yang isinya melarang Pegawai Negeri yang aktif di bidang politik. Kepemimpinan Nurmal Said kemudian dilanjutkan oleh Alhadar Alam. Secara garis besar perjalanan Parmusi Padang Pariaman banyak mendapat intervensi pemerintah, terutama pihak Pelaksana Khusus Daerah (Laksusda). Intervensi Laksusda itu dapat dilihat dengan peristiwa pencoretan 14 orang bakal calon legislatif Parmusi yang disinyalir merupakan mantan anggota Masyumi. Di samping itu setiap kegiatan rapat harus dilaporkan dan selalu diintai intel Polres Pariaman. Pelaksanaan Pemilu tanggal 3 Juli 1971 di Kabupaten Padang Pariaman diwarnai dengan kecurangan-kecurangan di beberapa Tempat Pemungutan Suara (TPS). Pada saat perhitungan suara dilakukan, seperti yang terjadi di Kampung Pondok dan di beberapa kecamatan terjadi kesalahan. Setelah diadakan penghitungan ulang, ternyata suara Parmusi semakin bertambah, meskipun masih belum mengalahkan dominasi Golkar.

\section{Daftar Pustaka}

Alam, Alhadar. t.t. "Mandeknya, Vakumnya Gerak Parmusi Padang Pariaman di bawah Ketua Drs. Raisuddin Muchtar", Manuskrip. Pariaman: Tidak Diterbitkan.

Anwar, Fortuna. (1985). "Ka'bah dan Garuda: Dilema Islam di Indonesia", Prisma No.4 April

Alfian.(1978). Pemikiran dan Perubahan Politik Indonesia. Jakarta: LP3ES.

Budiardjo, Miriam. (1981). Partisipasi dan Partai Politik. Jakarta: Gramedia .(1989). Dasar-Dasar Ilmu Politik. Jakarta: Gramedia.

Burke, Peter. (2003). Sejarah dan Teori Sosial. Jakarta: Yayasan Obor Indonesia

Daftar Tjalon Partai Muslimin Indonesia Tjabang Padang Pariaman untuk Daerah Tk.II Padang/Pariaman tanggal 13 Januari 1971.

Daftar Nama Ormas Pendukung dalam Piagam Partai Muslimin Indonesia tanggal 17 Agustus 1967.

Crouch, Harrold. (1999). Militer dan Politik di Indonesia. Jakarta: Pustaka Sinar Harapan.

Ensiklopedi Islam jilid 4 Jakarta: Ichtiar Baru vaan Hoeve, 1997.

Feith, Herber. (2001). Soekarno dan Militer. Jakarta: Pustaka Sinar Harapan.

Fatah, Eep Saefulloh. (1994). Negara Orde Baru dan Pengendalian Konflik Politik 19671988. Studi Peristiwa Malari, Petisi 50, Tanjung Priok”, Skripsi. Depok: FISIP UI.

Fatkhan. Muh. (2010). Jurnal Dakwah. Vol.XI No.2 Juli-Desember 
Abdul Salam Bulan Bintang Di Bawah Kuasa Beringin: Parmusi Padang Pariaman Masa Orde Baru

Haris, Syamsuddin. (1991). PPP dan Politik Orde Baru. Jakarta: Gramedia Widiasarana Indonesia

Instruksi Kepada Pimpinan Anak Tjabang Partai Muslimin Indonesia dalam Daerah Kabupaten Padang Pariaman tanggal 20 Djanuari 1971.

Katz, Richard S and William J Crotty. (2006). Handbook of Party Politics. Sage Publishig.

Karim, M. Rusli. (1993). Perjalanan Partai Politik di Indonesia Sebuah Potret Pasang Surut. Jakarta: Rajawali Pers

Kartodirdjo, Sartono. (1993). Pendekatan Ilmu Sosial Dalam Metodologi Sejarah. Jakarta: Gramedia.

Kuntowijoyo, (1994). Metodologi Sejarah. Yogyakarta: Tiara Wacana.

Kuper, Adam dan Jessica Kuper.(2000). Ensiklopedi Ilmu-Ilmu Sosial. Jakarta: Raja Grafindo Persada.

Keputusan Ke-I Partai Muslimin Indonesia di Malang tanggal 2-7 November 1968.

Keputusan Presiden Republik Indonesia No.70 Tahun 1968 tentang Pengakuan Berdirinya Partai Muslimin Indonesia

Keputusan Komisi KAPU, Arsip. (tanpa penerbit: Sidang Dewan Partai ke-III Partai Muslimin Indonesia, 1970),

Laporan Formasi Pimpinan Tjabang jang baru (Care Taker) tanggal 29 Sepetember 1972

Mikail, Kiki. (2015). "Pemilu dan Partai Politik di Indonesia. Menanti Kebangkitan Partai Politik di Tahun 20019”, Jurnal Tamaddun Vol.XV No.1 Januari-Juni.

Mintaredja, HMS.(1968). "Sekilas Sedjarah (memoire) tentang Pemerintah dan Pembentukan Partai Muslimin Indonesia.”, Manuskrip. Djakarta: Tanpa Penerbit.

Moertopo, Ali. (1982). Strategi Pembangunan Nasional. Jakarta: CSIS.

Tanter, Richard and Kenneth Young. (1993). Politik Kelas Menengah Indonesia. Jakarta: LP3ES.

Pidato Sambutan Bapak Mohammad Natsir pada pembukaan Sidang Dewan Partai ke-III Partai Muslimin Indonesia tanggal 15 Mei 1970

Raharjo, Dawam. (1983). “Menguak GBHN dalam Suasana Resesi”, Prisma No.1 Januari.

Romli, Lili. (2004). "Partai Islam dan Pemilih Islam di Indonesia.", Jurnal Penelitian Politik Vol.1 No.1.

SK Pimpinan Wilayah Parmusi Sumatera Barat No.093/C/1-70 tanggal 30 Maret 1970

SK PP Parmusi No.249/K.U./71 tanggal 16 Maret 1971

Surat Keputusan Nomor 214/1.- tentang Pengesahan Pimpinan Tjabang Partai Muslimin Indonesia Kabupaten Padang Pariaman

Surat Keputusan Pimpinan Partai "Partai Muslimin Indonesia” Nomor 214/1/29-68

Zed, Mestika, Edy Utama, dan Hasril Chaniago. (1996). Sumatera Barat di Panggung Sejarah. Jakarta: Sinar Harapan. 